\title{
Phakochronology: using fossilised lenticular scar to calculate rate of lens growth
}

\author{
Shorya Vardhan Azad, Sudarshan Khokhar, Amber Amar Bhayana 두, Anusha Agrawal
}

Ophthalmology, Dr Rajendra Prasad Centre for Ophthalmic Sciences, All India Institute of Medical Sciences, New Delhi, Delhi, India

\section{Correspondence to}

Dr Amber Amar Bhayana; amber.amar.bhayana@gmail. com

Accepted 28 December 2020

\section{DESCRIPTION}

A 58-year-old man gave a history of injury with chisel while hammering 16 years ago for which he did not seek any form of treatment and had no vision loss at the time. On examination, he had a self-sealed corneal perforation with a localised iris defect (figure 1A). On pupillary dilatation, a localised anterior fibrotic plaque was seen on the lens capsule and behind it was a lenticular opacity (figure $1 \mathrm{~B}, \mathrm{C}$ ); with a clear lenticular area between the two (figure 2A,B). Fundus showed a well-capsulated foreign body inferonasal to the disc with localised pigmentary changes (figure $2 \mathrm{C}$ ). The corneal perforation, the iris defect and the lenticular opacities all were present in the same straight line and were somewhat collinear with the location of foreign body in the posterior segment. They clearly represent the trajectory of the foreign body. Anterior segment optical coherence tomography was done through the lenticular opacity trajectory and the intralenticular opacity was found to be $480 \mu \mathrm{m}$ behind the anterior fibrotic capsule (figure 2A,B).

Crystalline lens is a unique organ in that it grows throughout life. Equatorial cells keep proliferating to produce new lens fibres which keep on accreting behind the anterior lens capsule. The old fibres are not shed but keep on accumulating interiorly causing what we know as nuclear sclerosis. ${ }^{12}$ So hypothetically, a mark if left on a lens fibre should embed deeper in the lens with time. In our case, the entry point opacity in the lens substance should have been on the surface. The fact that it is located $480 \mu \mathrm{m}$ posterior to anterior capsule suggests that equitorial lens epithelium must have remained active to produce $480 \mu \mathrm{m}$ of clear lens fibres over the time thus shifting the opacity posteriorly just like a fossil which got preserved inside the crystalline lens. Injury happened on 8 November 2004 (5854 days ago). So the time taken for these many

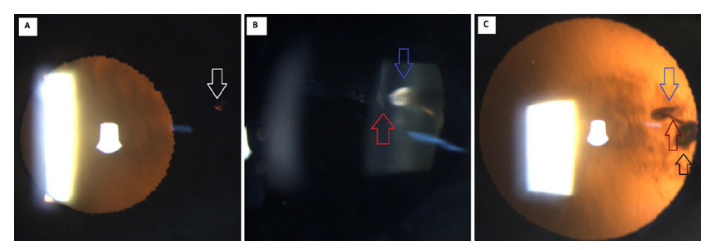

Figure 1 Right eye of the patient $(A)$ in retroillumination showing iris defect (white arrow); (B) oblique illumination showing anterior capsular plaque (red arrow), lenticular substance opacity (blue arrow); (C) retroillumimation in dilated pupil showing entry (blue arrow), passing track (red arrow) and exit (black arrow) of foreign body trajectory through the lens substance.

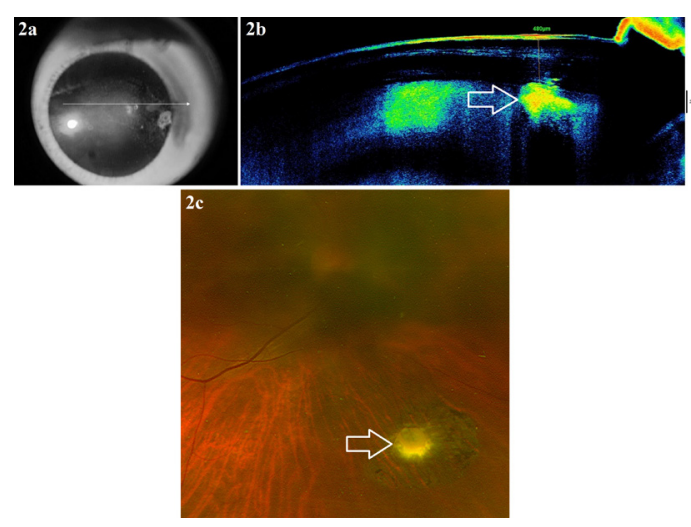

Figure 2 Anterior segment optical coherence tomography through section (A) of lenticular opacity showing lenticular substance opacity is $480 \mu \mathrm{m}$ posterior to lens capsule (B); (C) showing encapsulated foreign body in the posterior segment (white arrow).

microns of lens fibres to accumulate was 5854 days. Theoritically speaking, we can calculate the rate of production of lens fibres to be around $81.99 \mathrm{~nm} /$ day or $0.030 \mathrm{~mm} /$ year. In vivo lenticular growth rates in adults have been documented in very few studies and range from 0.013 to $0.025 \mathrm{~mm} /$ year. $^{3-6}$ In vitro rate of lens growth has been described to be $1.38 \mathrm{mg} /$ year increase of wet weight; $1.24 \mathrm{mg} /$ year in Indian population. ${ }^{27}$ The rate of lens fibre production might depend on the age and local environmental mileu with genetic variation as well. The rate of lens growth that we have calculated is individualised to this currently 58 -year-old man who had a history of open globe injury with direct lenticular trauma. The rate of lens fibre production in linear dimension (as calculated by us) may not exactly corraborate with the weight gain because nuclear compaction has not been taken into account and can not be predicted. The method we have used is called phakochronology which describes the technique for determining the time of events affecting the lens from the distance between the capsule and the region of interest. ${ }^{8}$ Hypothetically, one way to do is to inject a marker

\section{Learning points}

- Lens keeps growing throughout life.

- Any scar in lens (if preserved-if the lens does not turn completely cataractous) can help determine the rate of lenticular growth provided the exact time of lenticular insult is known. 
in vivo inside the crystallin lens and note its displacement over time. But, it will have ethical issues and such a study can never be conducted.

Contributors SK and SVA contributed to manuscript editing. AAB contributed to concept, diagnosis, manuscript preparation. AA contributed to retrieval of data.

Funding The authors have not declared a specific grant for this research from any funding agency in the public, commercial or not-for-profit sectors.

Competing interests None declared.

Patient consent for publication Obtained.

Provenance and peer review Not commissioned; externally peer reviewed.

\section{ORCID iD}

Amber Amar Bhayana http://orcid.org/0000-0002-0770-601X

\section{REFERENCES}

1 Smith P. Diseases of crystalline lens and capsule. 1. on the growth of the crystalline lens. Trans Ophthalmol Soc U K 1883:3:79-99.

2 Augusteyn RC. Growth of the human eye lens. Mol Vis 2007;13:252-7.

3 Brown N, Tripathi R. The loss of the anterior clear zone of the lens: Prognostict significance in cataract formation. Ocular disease. Transactions of the Ophthalmological Societies of UK 1974;94:29-45.

4 Dubbelman M, van der Heijde GL, Weeber HA. The thickness of the aging human lens obtained from corrected scheimpflug images. Optom Vis Sci 2001;78:411-6.

5 Jones CE, Atchison DA, Pope JM. Changes in lens dimensions and refractive index with age and accommodation. Optom Vis Sci 2007;84:990-5.

6 Strenk SA, Semmlow JL, Strenk LM, et al. Age-Related changes in human ciliary muscle and lens: a magnetic resonance imaging study. Invest Ophthalmol Vis Sci 1999;40:1162-9.

7 Mohamed A, Sangwan VS, Augusteyn RC. Growth of the human lens in the Indian adult population: preliminary observations. Indian J Ophthalmol 2012;60:511-5.

8 Huggert A. The thickness of the cortex of the crystalline lens in different ages. Acta Ophthalmol 1946;24:43-62.

Copyright 2021 BMJ Publishing Group. All rights reserved. For permission to reuse any of this content visit https://www.bmj.com/company/products-services/rights-and-licensing/permissions/

BMJ Case Report Fellows may re-use this article for personal use and teaching without any further permission.

Become a Fellow of BMJ Case Reports today and you can:

- Submit as many cases as you like

Enjoy fast sympathetic peer review and rapid publication of accepted articles

- Access all the published articles

Re-use any of the published material for personal use and teaching without further permission

Customer Service

If you have any further queries about your subscription, please contact our customer services team on +44 (0) 2071111105 or via email at support@bmj.com.

Visit casereports.bmj.com for more articles like this and to become a Fellow 